\title{
Apolysis, ecdysis, pharate adult, etc.
}

一昆虫変態の術語について——

\section{石 崎 宏 矩 \\ 名古屋大学理学部生物学教室}

Journal of Insect Physiology は，昆虫を材料とした 論文のみを揭載する権威ある雑誌である、ここに投稿し たことのある方のほとんどは，編集主幹の Hinton 氏か ら，昆虫の発生ステージの術語用法についてのクレーム をつけられた経験を括もちのはずである，彼のクレーム は，不思議なことに肝心の内容はさておき，もっぱらこ の種の術語用法に集中する. 彼の発生ステージの術語統 一にかける情熱は異常なまでに強く，彼の意に従わなけ れば載せてるらえないのだから，編集主幹としての実力 行使による影響力は絶大なものがある，仮に，「蛹化脱皮 後 3 日を経たカイコの蛹（pupa）を用いて…‥」といら 表現を用いたとしよう，彼は疑いるなく，「それは pupa ではなく， pharate adult であるはずである．俺の著作, Adv. Insect Physiol., Vol. 5, p.68〜71(1) をよく読ん だ上この種の誤りを訂正せよ」といってくるにちがい ないのである.

われわれの日常に，体験的な言葉としてまで定着して

7) A. J. Howells \& L. M. Birt : Comp. Biochem. Physiol., 11, 61 (1964).

8) I. Agrell : Nature, 170, 543 (1952).

9) I. Agrell : Physiol. Insecta, 1, 91 (1964).

10) A. Devi, A. Lemonde, U. Srivastava \& N.K. Sarkar : Exptl. Cell Res., 29, 443 (1963).

11) B.Linzen \& G. R. Wyatt : Biochim. Biophys. Acta, 87, 188 (1964).

12) Y.Chinzei : J.Insect Physiol., 20, 2333 (1974).

13) F.Engelmann: "The Physiology of Insect Reproduction", Pergamon Press, London, 1970, p. 307.

14) M. Ashburner: Adv. Insect Physiol., 7, 1 (1970).

15) M.M. Neult : Biochim. Biophys. Acta, 149, 422(1967).

16) D. D. Brown \& C. S. Weber : J. Mol. Biol., 34, 661(1968).

17) D. D. Brown \& C. S. Weber : J. Mol. Biol., 34, 681(1968).

18) J.G.Gall : Genetics Suppl., 61, 121 (1969).

19) J.G.Gall, E.H. Cohen \& M.L.Polan : Chromosoma (Berl.), 33, 319 (1971).

20) Y.Chinzei : J. Insect Physiol., 21, 163 (1975).

いる ‘蛹’といった言葉をそのままの感じで使うと， Hinton 氏のお怒りにふれるのであり，昆虫についての 素人が, pharate pupa, pupa, pharate adultなどとい った術語を使い分けなければならないとなると，多くの 方は途方にくれるのではなかろらか。矮小な意味では, J.I.P. に論文を採択されるためにはこの種の術語の理 解が必須であり，もっと高所にたってみてる，一般に昆 虫の発生の実状認識に不充分な側面があることは事実で あって,これを正確に把握して拉くことは大切なことで あることにはまちがいない、今まで縁のなかった昆虫を 実験材料とする人が急増している折からこの辺の事情 を明らかにしておくことは有用なことではなかららかと 考えたのが，この小文を記した理由である.

まず,われわれに最す身近な実験材料の一つであるカ イコの変態を頭に思い浮かべながら，図1を見ていただ

21) H. Shigematsu \& H. Takeshita : J.Insect Physiol., 41, 1013 (1968).

22）渡辺忠雄 : 日查雑，28，251 (1959).

23）鎮西康雄：日本応用動物昆虫学会大会講演要旨集，1973, p. 156.

24) S.Matsuura, T.Morimoto, S. Nagata \& Y.Tashiro: J.Cell Biol., 38, 589 (1968).

25) V.B. Wigglesworth:Quart.J.Micr.Sci., 83, 141(1942).

26) V.B. Wigglesworth:Quart.J.Micr.Sci., 89, 197(1948).

27) V.B. Wigglesworth : "The Principles of Insect Physiology", Methuen \& Co., 1965, p. 741.

28) W. H. Telfer: Ann. Rev. Entomol., 10, 161 (1965).

29）倉田啓而, 竹下弘夫, 重松孟, 坂手栄：日奣雑, 43,296 (1974).

30) Y.Suzuki, L.P.Gage \& D.D.Brown : J.Mol. Biol., 70, 637 (1972).

31) Y.Suzuki \& D. D. Brown : J.Mol. Biol., 93, 409 (1972).

32）石田政弘：蛋白質 核酸酵素 (別冊), 生命の起源と進化, p. 200 (1972).

33）杉野幸夫，岡崎令治：蛋白質 核酸酵素，2，98 (1957). 


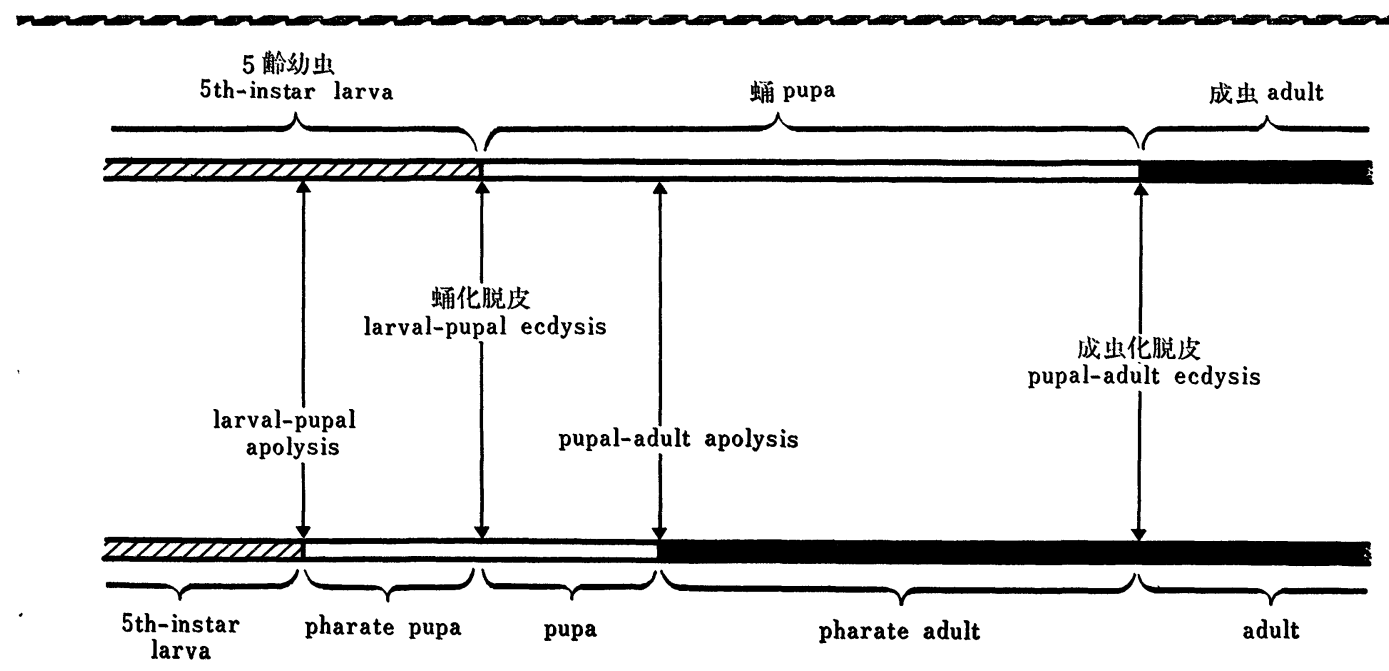

図 1 カイコのステージ分け

きたい，因の上側に示した発生期の呼び名は，抢そらく ほとんどの方にとって最もなじみの深いるのであろうと 思われる，これをみる限りでは，ステージの区別は明快 であり，文句をつける必要はなさそらにみえる。

このよらなステージ分けに対して Hinton は，脱皮の 代りにapolysisをステージの区切りにすべきであると主 張する・脱皮といら現象は，実際に古いクチクラを脱ざ捨 てるといら行為を最終過程として，一連の複雜な過程の 連続で構成されている（この全過程を総合して molting とよび，最終的に皮を脱ぐ行為そのものを ecdysis と よんで区別しているが，日本語に訳すと両者とも，“脱皮”， となってしまうことに留意されたい)。この molting の 全過程のらち，最初に起こる形態学的に可視的なことが らは，今まで表皮細胞密着していたクチクラが遊離し て，両者の間に空所が生ずることである．この現象を apolysis とよぶ（適当な日本語訳がない，強いてよべ ば、クチクラ遊離とでるいらべきか)、この事実は，す でに 1935 年に Snodgrass によって認められて, 'physiologically' $そ$ 'biginning of the instar' であると認 識され, 1966 年 Jenkin と Hinton によって apolysis と命名された。

もし、クチクラと密着したままで表皮細胞が増殖した とすると，表皮細胞層はクチクラといらギブスをはめら れたかっこうになっているわけであるから，成長した細 胞群ははみだす余地がなくて，その居場所に困るわけで ある。事実, apolysisなしに表皮細胞の増殖は決して起 こらず, apolysis は表皮増殖のための必須前駆条件とな
っている. apolysisを境として, 表皮のみならず体内諸 組織では，次のステージの体制への変革が行なわれ始め る. カイコの蛹から成虫への発生を例にとってみよう. 蛹化脱皮後, 約 1 日で前胸腺は変態ホルモン, エクジン ンを充分量分泌し，ほどなく apolysis が起こる，ひき つづいて，外形はまさに蛹のままであるが，虫体内では 表皮細胞の増殖，脂肪体細胞の解離や成虫型への再構成， 成虫原基の急激な成長などが起こって，着々と成虫の体 制が構筑されていく，したがって，その虫は成虫へと一 歩をふみ出して育ちつつあるのであって，蛹のからをか ぶってはいるが，むはや蛹ではないという見方が成立す るわけである.

古くから多くの昆虫生理学者は，このようなステージ を外観の蛹より内容の成虫をとって, developing adult とよんでいたが, Hinton は 1946 年, 'pharate adult' (pharate はギリシャ語で，抒拈いかくされた，あるい は外とう，の意. 古い蛹のクチクラでおおわれた成虫の 意となる)とよぶことを提唱した。このように，apolysis を各ステージの始まりとし，さらに各ステージを2つに 一たとえば成虫ならば pharate audlt と真の adult とに一区分することが提唱され，Hinton 式ステージ 分けとして, 因 1 下側の四式に示されるるのが成立した わけである.

Hinton は，このように扱らと脱皮を境としたステー ジ分けに比べて，さまざまの利点が生ずることを強調す 


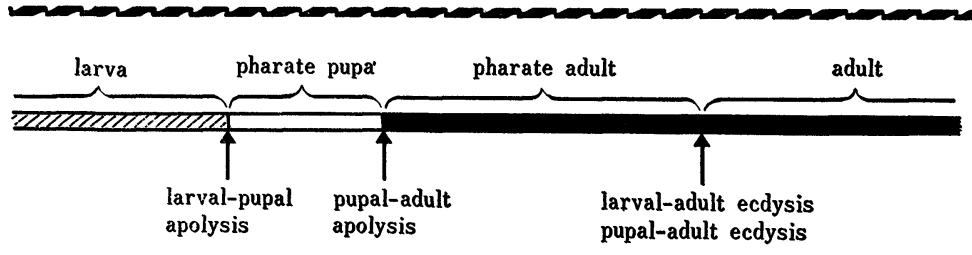

図 2 双翅目環縫覀目 Cyclorrhapha のステージ分け 蛹化脱皮がなく，羽化のときに幼虫クチクラ，蛹ク チクラを同時に脱ぎすてる.乙たがって，蛹期は全 期が pharate pupa とい5ことになる.
いことが望ましい.

ところが, apolysis の時点を知る ことは必ずしも容易ではない，解剖 䫒微鏡下で観察して,クチクラと表 皮の間にへだたりが生じ，体の表面 をつついてみてクチクラと表皮がず れた動きをみせれば，確実に apoly-
る.たとえば, ミノガ（ミノムシ）の多くの種では，成 虫は脱皮を行なわず, 終生蛹のクチクラで完全に拈おわ れたままであり，単為生殖を行なって肧は胎生によって 成長し，かなり大きくなった幼虫が親の体をくい破って 出てくる．脱皮を指標とすることに厳格に従えば，この 虫には成虫期がないといらことになるし，事実，一昔前 そは蛹のまま生殖する neoteny の現象とみなされたこ とすあったくらいである，事実は，apolysis に始まり成 虫ククチラの分泌至る成虫分化は，通常通り行なわれ ており、ただ蛹のクチクラを脱がないといら特殊なかた ちをとっているだけのことであって, apolysis を起点と する考えにたてば，混乱なく正当に成虫期を把握するこ とができるのだと主張する.

あら一つ, 双翅目環桻㩊目 Cyclorrhapha（ニクバエ, ルリバエ、ショウジョウバエなど）の例を彼は強調する. この亜目では，幼蚆ら蛹への変化の際に蛹化脱皮を行 なわず，幼虫クチクラがそのまま tanning され，その 下に蛹クチクラが分泌されて，幼虫と蛹のクチクラが合 体して蛹皮を作るといら特殊な経過をたどる、八エでは， 蛹の硬く茶色いクチクラを囲蛹殼 puparium とよんで， 他の一般の昆虫での pupal cuticle と区別しているのは この事情のためである. 結果として，図2に示したよう に，成虫が羽化する䟢に幼虫クチクラと蛹クチクラを同 時に脱ぐといら変則的な様式が形成されている.ここで, るし脱皮をステージの区切りにおくならば， ハエでは蛹 期が存在しないことになるが，apolysis を指標とするな らば、無理なく蛹のステージを把握できるという．

Hinton 式は一見したところ，なるほど合理的であり， すっきりした感を与えるように感じられる。しかし，実 際にはその震に少なからぬ難点が蔵されている，最大の 難点は，その実用性に和ける欠陥である、ステージ分け といらすのは, 本来, 実用面からの要求度の高いるので あり,誰にです簡単に判定でき,かつまぎらわしさのな sis が起こっていると判断してよい. しかし，種類によ ってはクチクラが厚く不透明で，熟練した研究者がみて る容易に判断のつかないことが多い，組織標本を作って みても、クチクラと表皮はわずかの衝撃ではがれるので, 包埋，切片製作の操作の間に生じた人工的㔀離と，真の apolysis とをみわけることは必ずしも容易でない。 た， apolysis の時期が記載されている種類はごくわずか しかないので，文献にたよることもできない，さらに， 体の部域によって apolysis が起こる時期に遅速があり， 一般に前部が早く後部が迤い傾向がある. 種類によって は部域差に一日の開きがある場合もあって，個体として ぞの時期を apolysis の時点とみなすかは厄介な問題で ある.

昆虫生理学の大御所ともいうべき Wigglesworth は, Hinton の J.I.P. の編集主幹としての“横举”にたまり かねたかのように, apolysis 区切り論に対する痛烈な批 判の論文を書き, ecdysis 区切り方式が結局は平易であ りまさっているとの主張を行なった(2). Hinton はさ らにこれを受けて立ち( ${ }^{(8)}$, 両者の論争はこの種の学術論 文としては異例の, 皮肉にみちた激しいやりとりを展開 している. 二人とる昆虫に関する超専門家であり，その らんちくを傾けてさまざまの種類をあげ, 形態, 生理, 生態, 行動などの多方面から現象をとらえて自説を主張 している. 現象の精細な把握は尊敬に值するが, 意地に なったこじつけ議論が散見され，学問的に格調が高いと はいい難い。ただ，昆虫の一つの特徵とるいえる種の広 沉な進化による高度の特殊化の実体にふれる意味で, こ れらの論文は一読に值するし，また野次馬的にいっても 退屈な小説を読むよりはるかに括るしろいことは保証で きる.

一例をあげておこう，毛翅目（トビケラの類）の多く 
の種のいわゆる蛹は, 水中を遊泳し, 水上につき出た適当 な物体にゆき当るとそこによじのぼって成虫脱皮を行な ら.古来これは“蛹”が泳ぐと記載されてきたが, Hinton は，遊泳の機能を支える筋肉は成虫分化が始まって後に 形成されるすのであり，まさしく蛹であるステージでは 泳げず, 泳いでいるのは ‘pharate adult' なのだと主張す る.これに対して Wigglesworthは，それはそうとして る，遊泳の具となるオールの役を果たす足は，蛹が分泌 した pupal cuticle なのであり，それなくして泳げない のだから蛹とよんで何が悪からうという，果ては Wigglesworth は，「蛹か成虫かは虫にきいてみればよい。 虫はきっと蛹だと答えるにちがいない」といえば, Hinton は「私は虫にたずねてみた，虫は疑いをいれぬ明瞭 な表現で，俺は成虫だと答えた」とやり返す。

こんな調子にまきこまれてみてる始まらない。いうま でるなく，われわれは何を学び，何を理解し，何をまち がえないようにすべきかが大切なことである.

第一に, molting といら現象が, apolysis に始まり， ecdysis に終る複合過程であることはまぎれるない事実 である. ecdysis があまりに目に鮮かなことの反動であ ろらか, apolysis の重要性は一般にあまり透していな いきらいがある. 昆虫のいろいろな生理状態が, ecdysis を境として大きく変わることが多いのは事実であるが, apolysis を境としてきわだって変わることる多いことを 心にとめて拈くことは，実験プランをたてる際に役立つ ことである. 自分の报っている材料では, いつ apolysis が起こり，次いでどのよらな発生経過をたどるのかを， できれば自分の目で確かめておくことは望ましいことで あるし，それが大儀とあれば, せめて誰かにきいて理解 しておくことは大いに有用なことと考えられる.

さらに，用語はしょせん用語であって，要はいわんと するところが正確に他人に伝えられればそれでよいので ある. Wigglesworth と Hinton の間でさ光決着がつか

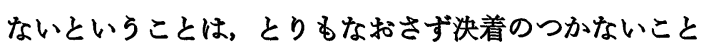
がらであることを意味しているといえようし，あまり神 経質にかかずらわるのは無意味なことである、あえて理 をたっとぶならば, Hinton 流のほらがやや分があると いえよらが, 平易さをたっとぶことも悪いことではない.
前述したミノガや八エの例で，脱皮による区切り法では, 成虫期や蛹期の始まりをどの時点におけばよいかが不分 明になるといら久陥は確かにあるが, 成虫期や蛹期が存 在しないことになってしまうとまでいらのは明らかにこ じつけである. 特殊例として，実態をよく認識しておき さえすればそれでよいと考劣られる，要は，内容を充分 理解した上で，自分の納得した術語を使らべきであろら。

ただたと党ば気軽に 3-day-old pupa と書いたとき にそれがすでに成虫分化を開始した状態を単に不用意 に表現したるのなのか, あるいは蛹化脱皮後 3 日でまだ 本当に pupa の状態にあるすのを敛密に表現したるのな のかが, 前後の状況から判断し難い場合もありらるし, その際, そのいずれであるかによって結果の吟味に差が 生じてくることがあることは事実である. Hinton がい みじくるいっているように, 自信がるてないときには, せめて individuals 3 days after pupal ecdysis といら ように,だれの目にも判然とした現象を起点とした時間 の経過を指定するような配慮さえ行なわれれば，ずい分 と混乱がさけられようといら意見が, 最も妥当な結論と 思われる.では，実際にどのような場合にどう書くとま ぎらわしいのか, そのときにはどら書けばよいのか, と いら虎の巻が書ければ一番役に立つのであろらが, 応用 問題は多様であって, 残念ながら簡潪なダイジェストを 作って沶示しすることはできそらにない。はなはだ物足 りない結論となるが，論文を書かれるときは，やはり一 度は文献 1）に目を通しておくことをおすすめする次第 である.

\section{文献}

1) H.E.Hinton: Definition of stages during metamorphosis, Adv. Insect Physiol., 5, 68 71 (1968) の Spiracular Gills 中の一章.

2) V.B.Wigglesworth : The significance of "apolysis" in the moulting of insects, J.Ent. (A), 47, 141 149 (1973).

3) H.E.Hinton : Neglected phases in metamorphosisA reply to V.B. Wigglesworth, J. Ent. (A), 48, 57 $\sim 68$ (1973).

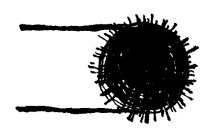

